\title{
Mediation: The Best Way Forward in Conflict Prevention and Resolution
}

Amb. (Ret.) Ertuğrul Apakan ${ }^{1}$

\section{Introduction}

In recent years, we have seen a growing interest in and support for mediation as a means of preventing conflicts and resolving disputes, not only at the United Nations (UN) headquarters, but also at regional and national levels. As the Permanent Representative of Turkey to the United Nations since 2009, I have witnessed the momentum built around the concept of mediation. Turkey, as the co-chair of the Group of Friends of Mediation, played a leading role in this process. Its membership in the UN Security Council in 2009-2010 also helped Turkey pursue and contribute to this matter within the Council.

Today's security environment demands the UN's increased attention through different means and tools. Out of the 67 peacekeeping operations that have been deployed in UN history, 54 have been established since 1988. The Security Council currently has over 70 conflicts in its agenda. Two-thirds of these conflicts are related to Africa and the least developed countries. A bulk of UN expenditures is allocated to peacekeeping operations, and the increasing burdens and costs of peacekeeping in the midst of a global financial crisis have also contributed to the rediscovery of preventive diplomacy and mediation as significantly less-costly crisis management options.

Mediation and other means of prevention and peaceful conflict settlement are among the UN's core missions. Chapters I and VI of the UN Charter include provisions about these concepts and tools. The founders of the UN saw merit in mediation, and specifically reflected it in Chapter VI, Article 33. However, mediation was not able to blossom at that time, because the years that followed saw the onslaught of the Cold War.

In 1992, upon the call of the Security Council, then-Secretary-General Boutros BoutrosGhali prepared his 1992 milestone report, an "Agenda for Peace". Then, at the 2005 World Summit, the UN Member States agreed in the Outcome Document that they have a joint responsibility to use appropriate diplomatic, humanitarian and other peaceful means to resolve conflicts, and that the mediation capacity of the Secretary-General should be strengthened.

Most interstate conflicts are related to power politics and geopolitical realities. Internal causes of conflict arise from political, security and economic dynamics ${ }^{2}$. Therefore, innovative approaches to conflict resolution should be sought and used. In this context, protecting civilians becomes a priority. As a result, mediation and preventive diplomacy are gaining more and more importance in the UN's work.

While Turkey was a member of the Security Council, a summit was held in September 2010 under the chairmanship of Turkish President Abdullah Gül, where a milestone

Ertuğrul Apakan, Turkish Ambassador (Ret.). E-mail: ertugrul.apakan@gmail.com

1 I'd like to thank my former colleagues Aziz Sevi and İlker Kilıç for their contributions to this article in September 2012.

2 World Development Report 2011 - Conflict, Security, and Development (Washington: The World Bank, 2011). 
Presidential Statement encompassing peacekeeping, peacemaking, peacebuilding and preventive diplomacy, including mediation, was adopted. The Security Council underlined the increasing importance of mediation and its cost-effectiveness, and pledged to make more and better use of it.

In terms of using mediation to resolve disputes on the ground, recent success stories include the mediation initiatives in Kenya in 2007 and in South Sudan in 2011. There have also been some unsuccessful attempts in last two decades, particularly in Rwanda and Somalia and Bosnia-Herzegovina. These countries had faced cycles of repeated violence, weak governance and instability. This is also valid for other Sub-Saharan countries where new forms of conflict and violence threaten security and development. Against this backdrop, the growing cooperation between the UN, the African Union and sub-regional organizations such as ECOWAS brings cohesion and complementarity to the mediation efforts in the continent.

Mediation seems to be unsuccessful in the case of some complex and intractable conflicts in the Middle East. In Syria we are still experiencing an on-going political and humanitarian crisis, bloodshed and violence. The joint mediation initiatives by the UN and the Arab League did not yield any result.

Building on the acquis accumulated by the UN on mediation, the ministers of foreign affairs of Turkey and Finland decided to establish a Group of Friends within the UN. When the two countries launched the Mediation for Peace Initiative in 2010, they were convinced that the UN has a special role to play in leading mediation efforts. They know that UN engagement in itself lends credibility and legitimacy to mediation processes. Additionally, the UN's institutional capabilities and experiences in mediation surpass those possessed by any single organization or country in the world.

The Group of Friends acts as a bridge between the UN Secretariat, Member States, NGOs and civil society. It directly and indirectly supports activities carried out by the UN's Mediation Support Unit, which has valuable assets such as the Standby Team of Mediation Experts and as well as an additional roster of mediators. The UN is in a prime position to assure cooperation and coordination in mediation efforts so that different players complement and mutually reinforce each other's endeavours.

The Group of Friends also aims to provide more opportunities for civil society and NGOs and women to participate in mediation processes and network. Furthermore, a division of labour between Track 1 and Track 2 is crucial: more complementarity and cross-fertilization is necessary to establish innovative thinking in tackling different aspects of the conflict at hand.

The Group of Friends of Mediation has now grown to 34 Member States and eight regional and international organizations from around the globe. The mix of views, experiences and realities that members bring to the group's discussions and activities produces a synergy in diversity.

The purpose of the Group is to establish a more effective and more comprehensive network with the Secretariat, regional and sub-regional organizations, as well as with NGOs and civil society. With this understanding, in 2011 the Group of Friends spearheaded a General Assembly Resolution 65/283 entitled: "Strengthening the role of mediation in the peaceful settlement of disputes, conflict prevention and resolution". For the first time, the UN adopted a Resolution on mediation, which has become a central piece of its mediation architecture. 
This Resolution brings a new vision to UN, to regional and sub-regional organizations and to NGOs, providing a base on which we can build future efforts.

It was encouraging that following the adoption of this Resolution, the President of the General Assembly for the sixty-sixth session identified mediation as the main theme. Among other activities on this matter, he convened a high-level meeting of the General Assembly on 23 May, 2012. Hence, in his five-year action agenda (the priorities for his second term in office) the Secretary-General announced that he placed preventive diplomacy at center stage.

Apart from its efforts at the UN to promote mediation, Turkey has for some time been vigorously trying to resolve differences between countries and find solutions to chronic problems. Doing so, Turkey has benefited from a range of assets emanating from its historical, social and cultural ties, and from growing economic capabilities. In this context, Turkey's efforts at conciliation in Iraq and with the Middle East Peace Process, and in the Balkans, Central Asia, Afghanistan and Somalia, are just a few examples of its concrete endeavours in this regard.

The Alliance of Civilizations initiative, jointly co-sponsored by Turkey and Spain, and the Mediation for Peace prescribe the same cure for the maladies they address: dialogue. It is only through dialogue that we can ease tensions and conflicts between different parties; be it interfaith or political, economic or cultural. Dialogue is the only way to attain mutual understanding, reconciliation and peace.

Since many conflicts are of a chronic nature, persistence and perseverance are of critical importance. Mediators should avoid short-term, quick-fix solutions that tend not to be viable in the long run. ${ }^{3}$ Success might sometimes only be achieved after many failed attempts.

Mediation is a methodology as well as a process in the context of conflict management. There is no single recipe for successful mediation, just as no conflict is the same as another. Therefore, mediation efforts must be flexible, creative, innovative and adaptable to changing conditions. The mediator should speak in the same language to all sides of a conflict or dispute. Cultural differences must also be recognized and local approaches and people must be included in the mediation efforts. ${ }^{4}$

Mediation is at its best when it is complemented by others' efforts and when it facilitates ongoing endeavours. In that respect, there is no better actor than the UN for coordinating overall mediation work. There have been significant enhancements in the organization's capacity to support political and mediation missions from within the theatre of conflict. ${ }^{5}$ So far the UN has opened offices in Central Africa, West Africa and Central Asia to help prevent conflict and consolidate peace. They are making a very important contribution to the UN's efforts in preventing conflicts.

In this respect, Turkey is convinced that the proposed UN mediation center in Istanbul, would become an integral part of the UN's capabilities in preventative diplomacy and mediation. Taking into account its unique geographic position at the center of Afro-Eurasia and its proximity to many conflict zones, Istanbul offers an ideal location for such a mediation center.

\footnotetext{
"International Mediation - A Vision for the Future," (High-Level Seminar in Helsinki, Finland, June 28-July 1, 2012).

4 Summary Report of the Istanbul Conference on Mediation, February 24-25, 2012 (New York: United Nations A/66/800, May 12, 2012).

5 Arthur Boutellis and Christoph Mikulaschek, "Strengthening Preventive Diplomacy and Mediation: Istanbul Retreat of the UN Security Council," July 2-3, 2011,

http://www.ipinst.org/publication/meeting-notes/detail/353-strengthening-preventive-diplomacy-and-mediation.html
} 
At this critical juncture, when we witness increased threats and challenges to peace and security in many parts of the globe and the ongoing transformation process in the Arab world, it is necessary to render mediation more effectively at regional and national levels. The experiences in recent years have shown that if mediation is utilized in a timely manner, it is possible to prevent or stop atrocities, loss of lives, human suffering and violations of human rights. Therefore, it would be useful for the international community to further the concept of mediation at the UN and beyond for a more peaceful and stable future.

\section{Bibliography}

Boutellis, Arthur and Christoph Mikulaschek. "Strengthening Preventive Diplomacy and Mediation: Istanbul Retreat of the UN Security Council," July 2-3, 2011.

http://www.ipinst.org/publication/meeting-notes/detail/353-strengthening-preventive-diplomacy-and-mediation. html.

"International Mediation - A Vision for the Future.” High-level seminar in Helsinki, Finland, June 28-July 1, 2012.

Ban, Ki-moon. Report of the Secretary-General on "Strengthening the role of mediation in the peaceful settlement of disputes, conflict prevention and resolution." New York: United Nations A/66/811, June 25, 2012.

United Nations. "Summary Report of the Informal High-Level Meeting of the General Assembly on 'The Role of Member States in Mediation, 23 May 2012'." http://www.un.org/en/ga/president/66/Letters/index.shtml.

United Nations. Summary Report of the Istanbul Conference on Mediation, February 24-25, 2012. New York:

United Nations, A/66/800, May 12, 2012.

World Bank, The. World Development Report 2011 - Conflict, Security, and Development. Washington: The World Bank, 2011. 